\title{
Konsep Diversi sebagai Bentuk Kebijakan Sanksi Cyber Crime terhadap Anak di Bawah Umur
}

\author{
Amelia Haryantia, ${ }^{\mathrm{a}}$ * \\ aProgram Studi Pendidikan Pancasila dan Kewarganegaraan, \\ Fakultas Keguruan dan Ilmu Pendidikan, Universitas Pamulang, Tangerang Selatan \\ ${ }^{1}$ dosen00811@unpam.ac.id \\ *korespondensi penulis
}

Naskah diterima: 30-08-19, direvisi: 20-09-19, disetujui: 28-09-19

DOI: http://dx.doi.org/10.32493/jpkn.v6i2.y2019.p105-122

\begin{abstract}
Abstrak
Konsep kebijakan diversi sebagai bentuk alternatif penyelesaian permasalahan terhadap anak yang bermasalah dengan hukum. Ketika seorang anak harus berhadapan dengan hukum sebagai seorang pelaku kejahatan, maka penegakan hukum terhadap anak pelaku kejahatan harus ditegakan melalui lembaga peradilan yang ada di Indonesia.. Tujuan dari penelitian ini adalah memberikan pemahaman kepada penegak hukum dalam melaksanakan mekanisme penyidikan cyber crime, pelaksanaan kebijakan tindak pidana cyber crime, dan menjelaskan hubungan konsep restorative justice dengan konsep diversi dalam penyelesaian perkara anak. Penelitian ini menggunakan metode penelitian empiris atau juga disebut penelitian hukum sosiologis. Hasil penelitian menunjukan bahwa mekanisme penyidikan cyber crime menurut KUHAP dihubungkan dengan Sistem Peradilan Pidana Anak, pelaksanakan kebijakan tindak pidana cyber cryme terhadap anak dan hubungan konsep restorative justice dengan konsep diversi pada penyelesaian perkara anak harus menjadi perhatian bagi aparat penegak hukum dalam menerapkan kebijakan terhadap anak.
\end{abstract}

Kata-kata kunci: penyelesaian perkara; sanksi cyber crime; anak di bawah umur

\section{Abstract}

The concept of policy is diversified as an alternative form of problem solving for children with legal problems. When a child must face the law as a criminal, law enforcement against a child criminal must be enforced through a judicial institution in Indonesia. The purpose of this study is to provide understanding to law enforcement agencies in carrying out cyber crime investigation mechanisms, implementing action policies criminal cyber crime, and explain the relationship between the concept of restorative justice and the concept of diversion in the settlement of child cases. This research uses empirical research methods or also called sociological legal research. The results showed that the mechanism of cyber crime investigation according to the Criminal Procedure Code was connected with the Child Criminal Justice System, implementing a cyber cryme crime policy against children and the relationship between the concept of restorative justice and the concept of diversion in the settlement of child cases should be a concern for law enforcement officials in implementing policies against children.

Keywords: case settlement; cyber crime sanctions; minors 


\section{Pendahuluan}

Sebagai generasi penerus bangsa yang akan menggantikan pemimpin-peminpin negara di masa depan hak-hak anak wajib di lindungi oleh pemerintah dan masyarakat. Anak sebagai harapan bangsa harus diberikan kesempatan untuk tumbuh menjadi generasi yang berkembang secara wajar sesuai dengan perkembangan usianya sehingga mampu beradaptasi dengan lingkungan sosialnya. Pemerintah wajib melindungi hak-hak anak agar tumbuh kembangnya dapat mendukung masa depannya. Melindungi tumbuh kembang anak sebagai suatu keharusan bagi seluruh lapisan masyarakat, karena anak merupakan aset masa depan bangsa, kelak mereka yang menggantikan generasi kita. (Maidin Gultom, 2014:2)

Namun seiring dengan berkembangnya zaman, banyak anak-anak yang terlibat kasus tindak pidana pencurian, pemalsuan, pembunuhan, pemerkosaan, bahkan terlibat dalam tindak pidana kejahatan dunia maya (cyber crime). (Maidin Gultom, 2014:40)

Banyaknya anak yang terlibat kasus hukum menimbulkan keprihatinan bagi kita semua. Pada tahun 2018, komisi perlindungan anak mencatat bahwa kasus pidana yang menjerat anak-anak masih tinggi, tercatat sekitar 1209 kasus, dan sekitar 514 kasus adalah karena cyber crime. Tingginya kasus pidana yang menjerat anak-anak ini biasanya dikarenakan mereka juga sebelumnya pernah menjadi korban kejahatan, faktor lingkungan bermain, dan juga pola pengasuhan orang tua yang kurang baik.
Secara hukum anak-anak belum cakap untuk dituntut secara hukum, namun penegakan hukum bagi pelaku kejahatan anak-anak ini juga harus ditegakan. Dapat dikatakan bahwa terkadang penerapan sanksi ini mengabaikan umur anak. Sebagai aset bangsa dan calon generasi masa depan, peran anak sangat strategis sebagai penerus perjuangan bangsa. Peran ini diakui oleh masyarakat Internasional sehingga lahirlah konvensi tentang perlindungan anak yang menekankan hakhak anak yang wajib dilindungi oleh segenap lapisan masyarakat.(Ruben Ahmad, 2004:24)

Untuk menjamin perkembangan mental dan psikisnya, anak wajib mendapatkan pembinaan dan perlindungan agar tumbuh menjadi generasi yang diharapkan bangsa, tidak terkecuali, pembinaan ini juga harus dilakukan terhadap seorang anak yang sedang menghadapi kasus hukum. Hal ini diatur dalam penjelasan 23 Tahun 2002 tentang Perlindungan Anak yang menyebutkan bahwa: "anak adalah amanah sekaligus karunia Tuhan Yang Maha Esa, yang senantiasa harus kita jaga karena dalam dirinya melekat harkat, martabat dan hak-hak sebagai manusia yang harus dijunjung tinggi."

Terkait dengan permasalahan tersebut, maka penelitian ini hanya akan meneliti tentang: 1) bagaimana mekanisme penyidikan cyber crime dengan pelaku anak menurut KUHP dihubungkan dengan UU Tentang Peradilan Pidana Anak No. 11 Tahun 2012, 2) bagaimana kebijakan tindak pidana cyber cryme terhadap anak, 3). 
Bagaimana hubungan konsep restorative justice dengan konsep diversi dalam penyelesaian perkara anak?

Penanganan kasus hukum yang menjerat anak harus dibedakan penanganannya dengan orang dewasa yang melakukan kejahatan, hal ini dilakukan demi perkembangan mental dan psikis anak di masa depan. Sebagai bentuk perhatian pemerintah terhadap maraknya kasus-kasus yang menjerat anak-anak, maka dilakukan perubahan Undang-Undang Nomor 23 Tahun 2002 Tentang Perlindungan Anak yang pada tahun 2014 menjadi Undang-Undang Nomor 23 Tahun 2002 tentang Perlindungan Anak. Namun dengan perubahan ini belum dapat meminialisir tingkat kejahatan yang dilakukan oleh anak.

Berbagai penelitian yang telah dilakukan Penegakan Hukum Kejahatan Dunia Maya (Cybercrime) Yang Dilakukan Anak Di Bawah Umur (Bayu Anggara dan I Nyoman Darmadha, 2017), Penyidikan Tindak Pidana Yang Dilakukan Oleh Anak Berdasarkan Undang-Undang Nomor 11 Tahun 2012 Tentang Sistem Peradilan Pidana Anak Oleh Penyidik Kepolisian Sektor Koto Tangah Kota Padang (Aditya Adha, 2018), Penyidikan Terhadap Anak sebagai pelaku Tindak Pidana pelecehan Seksual oleh Penyidik Unit PPA Satuan Reskrim berbasis Keadilan Restoratif di Kabupaten kendal (Agil Widiyas sampurna dan Suteki, 2016), mendapat temuan serupa yakni mengungkapkan penyelesaian kasus yang menimpa anak, namun perbedaan dalam penelitian ini adalah konsep yang
Journal of Civics and Education Studies p-ISSN 2302-0865 | e-ISSN 2621-346X

digunakan dalam penyelesaian masalahnya.

\section{Metode}

Penelitian yang dilakukan adalah dengan menggunakan jenis penelitian hukum dengan penelitian hukum empiris atau disebut juga penelitian hukum sosiologis. Data yang diperoleh dalam penelitian empiris yakni dengan terjun langsung ke lapangan dan data yang diperoleh langsung dari masyarakat. Pada umumnya penelitian hukum mempunyai dua tipe yakni yuridis normatif dan yuridis empiris, namun dalam penelitian ini penulis menggunakan penelitian dengan pendekatan yuridis empiris atau sosiologi hukum. (Zainidin Ali:1997:91).

Adapun yang menjadi populasi dalam penelitian ini adalah anak-anak pelaku tindak pidana cyber crime di kota Tangerang Selatan. Sumber data yang digunakan dalam penelitian ini polrestaTangerang Selatan, sedangkan data yang digunakan adalah tipe penelitian hukum empiris atau penelitian hukum sosiologis, yang terdiri dari data primer dan data skunder. Teknik pengumpulan data yang dilakukan oleh peneliti yakni dengan teknik observasi dan wawancara. Wawancara yang dilakukan berupa tanya jawab yang dilakukan oleh penulis dengan narasumber. (Ronny Hanitijo, 1982:62) Selain dengan teknik diatas, penulis juga melakukan pencarian melalui kepustakaan yang bersumber pada perundang-undangan, jurnal-jurnal, buku, dokumen, hasil publikasi, hasil penelitian. (Joko Subagyo, 1997:91) 
Hasil dan Pembahasan

Mekanisme penyidikan cyber crime oleh anak menurut KUHAP dihubungkan dengan UU Sistem Peradilan Pidana Anak

Indonesia sangat rentan sekali terjadi tindak pidana, ini terbukti dengan banyaknya tindak pidana yang terjadi tanpa melihat usia dari pelaku bahkan seringkali dilakukan oleh anak-anak. Sebagai generasi penerus untuk meneruskan cita-cita bangsa, anak perlu diberikan kesempatan untuk menikmati masa-masa indah pertumbuhannya baik secara rohani maupun jasmani dalam kehidupan lingkungan sosialnya, untuk itu diperlukan perlindungan terhadap hakhaknya oleh seluruh lapisan masyarakat.(Ledy Dina, 2011:151).

Dibedakannya penyidikan terhadap kejahatan yang dilakukan oleh orang dewasa dengan anak-anak bertujuan agar ketentuan Undang-Undang yang digunakan dalam melaksanakan proses penyidiikan dapat dilaksanakan sesuai dengan ketentuan perundang-undangan sehingga mental anak yang sedang menghadapi kasus hukum dapat terjaga. (Maidin Gultom, 2012:13), Misalnya ketika penyidik mengajukan pertanyaan kepada anak saat penyidikan berlangsung, biasanya penyidik apabila melakukan penyidikan terhadap orang dewasa akan tercipta suasana tegang, namun ketika proses penyidikan terhadap anak harus dilakukan oleh penyidik khusus anak agar suasana penyidikan berlangsung secara kekeluargaan sehingga tidak mengganggu mental anak saat penyidikan berlangsung.
Hal ini diatur dalam pasal 26 ayat (4) Undang-Undang Nomor 11 Tahun 2012 tentang Sistem Peradilan Pidana Anak yang menyatakan bahwa: "dalam hal belum terdapat penyidik yang memenuhi persyaratan sebagaimana dimaksud pada ayat 3 , tugas penyidikan dilaksanakan oleh penyidik yang melakukan tugas penyidikan tindak pidana yang dilakukan oleh orang dewasa". Upaya penangkapan, penahanan maupun pemenjaraan terhadap pelakunya seorang anak wajib didasarkan pada ketentuan perundang-undangan tentang perlindungan anak, dan ini dijalankan hanya sebagai bentuk upaya terakhir, dan prosesnya harus dijalankan dengan waktu yang sesingkat-singkatnya. Oleh karena itu pemerintah mensahkan perundang-undangan sistem peradilan anak sebagai bentuk perlindungan terhadap hak-hak anak yang bermasalah dengan hukum agar martabat dan harkat seorang anak tetap terjaga.

Proses pemeriksaan penyidik dalam mengintrogasi tersangka anak di bawah umur dalam tindak pidana

Pelanggaran hukum yang dilakukan oleh anak dibawah umur adalah berasal dari perbuatan manusia yang tumbuh dalam menjalani kehidupannya dimasyarakat. Oleh karena itu untuk menanggulangi semakin berkembangnya pelanggaran hukum yang dilakukan oleh anak-anak, maka peran serta masyarakat harus dilibatkan untuk bersama-sama dengan aparat penegak hukum dalam penaggulangan kejahatan, tindak pidana anak dibawah umur, karena dalam memerangi kejahatan merupakan tugas 
kita bersama, tidak hanya tugas tanggung jawab pemerintah saja dalam penanganannya, namun bersama dengan kekuatan masyarakat maka kita bisa meminimalisir kejahatan anak.

Pemeriksaan terhadap pelaku merupakan rangkaian kegiatan untuk mendapatkan keterangan dan kejelasan yang teridentifikasi dengan tersangka maupun saksi serta adanya barang bukti yang terlibat atau yang digunakan ketika tindak pidana tersebut terjadi. Dari proses rangkaian kegiatan pemeriksaan tersebut akan dituangkan dalam berita acara pemeriksaan. Penyidikan dilakukan oleh penyidik atau pembantu penyidik atas dasar: a. Laporan yang diajukan oleh polisi, b. Laporan dari hasil peyidik setelah melakukan penyelidikan yang diperintahkan oleh penyidik atau penyidik pembantu sebagai petugas yang berwenang melakukan peyidikan, c. Selesainya berita acara pemeriksaan di tempat kejadian perkara (TKP), d. Adanya petunjuk dari jaksa untuk melaksanaan pemeriksaan tambahan, e. Apabila tersangka berada diluar wilayah hukum penyidik, maka dapat meminta bantuan kepada penyidik yang berada di wilayah hukum tersangka.

Teknik pemeriksaan dapat dilakukan dengan cara: a. Interview, yakni upaya yang dilakukan penyidik atau penyidik pembantu dalam mendapatkan keterangan dari orang-orang yang terduga memiliki keterangan yang dibutuhkan dalam proses penyelesaian perkara, b. Inteterogasi adalah melakukanpemeriksaan terhadap tersangka atau saksi dengan pertanyaanpertanyaan secaara lisan maupun tertulis untuk memperoleh keterangan dalam rangka mengungkap kejahatan, c. Konfrontasi adalah upaya yang dilakukan oleh penyidik dengan cara mempertemukan orang-orang yang bertindak sebagai saksi atau tersangka untuk menguji kebenaran, persesuaian atau bahkan perbedaan untuk dituangkan dalam berita acara konfrontasi, d. Rekonstruksi, yakni memperagakan kembali tahapan-tahapan terjadinya tindak pidana untuk mendapatkan faktafakta yang terjadi sesuai dengan keterangan pelaku dan korban maupun saksi ketika peristiwa tersebut terjadi. Reka adegan ini digunakan penyidik untuk meyakinkan penyelidikan sebagai kebenaran tentang peristiwa kejahatan yang telah dilakukan ditempat kejadian perkara.

Penyidik waajib menberitahukan hakhak tersangka sebelum peyidikan dimulai, hal ini diatur dalam pasal 56 ayat 1 KUHAP yang berbunyi: "Dalam hal tersangka atau terdakwa disangka atau didakwa melakukan tindak pidana yang diancam dengan pidana mati atau ancamanlima belas tahun atau lebih atau bagi mereka yang tidak mampu yang diancam dengan pidana lima tahun atau lebih yang tidak mempunyai penasehat hukum sendiri, pejabat yang bersangkutan pada semua tingkat pemeriksaan dalam proses peradilan wajib menunjuk penasehat hukum bagi mereka". Apabila tersangkanya adalah anak dibawah umur, maka dalam pemeriksaannya harus berpedoman pada Undang-Undang No 3 tahun 1997 tentang Peradilan Anak. 
Dalam pelaksanaan pemeriksaan, bahasa yang digunakan oleh penyidik harus dipahami dengan jelas oleh anak dan kepada tersangka berhak diberitahukan apa yang dipersangkakan ketika pemeriksaan di mulai. Penyidik juga wajib menanyakan, apakah kesaksian tersangka tersebut ingin didengarkan oleh saksi lainnya yang menguntungkan, apabila tersangka menginginkannya maka penyidik wajib memanggil saksi yang dimaksud. Ketika proses penyidikan berlangsung tidak diperkenankan adanya penekanan dan kekerasan dalam bentuk apapun, dan dalam proses ini harus selalu berpedoman pada aturan yang berlaku.

\section{Bentuk perlindungan hukum terhadap anak sebagai tersangka}

Menurut Lili Rasjidi:

"Perlindungan adalah pemberiian jaminan atas keamanan, ketentraman, kesejahteraan dna kedamaian dan pelindung atas segala bahaya yang mengancam pihak yang dilindungi. Perlindungan hukum adalah hal perbuatan melindungi menurut hukum". (Dahlan Sinaga, 2017:43). Hal senada di tegaskan oleh Suriaryati Hartono, yang mengatakan bahwa: "perlindungan dapat difungsikan untuk menciptakan kepentingan konsumen, para pengusaha, masyarakat, dan pemerintah, oleh karena keseimbangan-keseimbangan lama telah mengalami perombakan dan perubahan. Hukum dibutuhkan oleh mereka yang lemah dan belum kuat secara sosial, ekonomi dan politik".

Dalam pasal 2 bab II Undang-Undang Republik Indonesia No. 35 Tahun 2014 dijelaskan bahwa asas dan tujuan dari perlindungan hukum adalah: "Penyelenggaraan perlindungan anak beradsaskan Pancasila dan berlandaskan Undang-Undang Dasar Negara Republik Indonesia Tahun 1945 serta prinsipprinsip dasar Konvensi Hak-Hak Anak meliputi: a). non diskriminasi; b).kepentingan yang terbaik bagi anak; c).hak untuk hidup, kelangsungan hidup, dan perkembangan; dan d).penghargaan terhadap pendapat anak", selanjutnya dalam Pasal 3 meliputi: "Perlindungan anak bertujuan untuk menjamin terpenuhinya hak-hak anak agar dapat hidup, tumbuh, berkembang, dan berpartisipasi secara optimal sesuai dengan harkat dan martabat kemanusiaan, serta mendapat perlindungan dan kekerasan dan diskriminasi, demi terwujudnya anak Indonesia yang berkualitas, berakhlak mulia, dan sejahtera".

Untuk perlindungan terhadap anak apabila usianya sudah mencapai 12 tahun namun belum mencapai 18 tahun dan belum pernah menikah menggunakan Undang-Undang No 3 Tahun 1997 yang telah direvisi oleh Mahkamah Konstitusi tentang perlindungan anak. Pasal 1 ayat 2 mengatakan: "Perlindungan Anak adalah segala kegiatan untuk menjamin dan melindungi Anak dan hak-haknya agar dapat hidup, tumbuh, berkembang, dan berpartisipasi secara optimal sesuai dengan harkat dan martabat kemanusiaan, serta mendapat perlindungan dan kekerasan dan diskriminasi"(Marlina, 2009: 23-25). 


\section{Pelaksanaan Kebijakan Tindak Pidana Cyber Crime Terhadap Anak}

Dalam UU No. 11 Tahun 2012 tentang peradilan anak menyatakan bahwa aturan ini menekankan kepada perlindungan dan mengayomi anak-anak yang sedang bermasalah dengan hukum agar di berikan kesempatan kepada anak untuk bisa menyongsong masa depannya dengan diberikan pembinaan agar manjadi manusia yang mandiri, bertanggung jawab, berbakti kepada orang tua, keluarga, nusa dan bangsanya. Diberlakukannya perundang-undangan ini agar anak terhindar dari perlakukan yang merugikan ketika harus menghadapi masalah hukum yang menjeratnya.

Aturan mengenai diversi dicantukan dalam pasal 6 sampai dengan pasal 14 UU No 11 Tahun 2012, selanjutnya dalam pasal 15 dicantumkan tentang pedoman pelaksanaan tata cara diversi, dan koordinasi pelaksanaannya diatur dalam peraturan pemerintah (Wiyono $\mathrm{R}$ 2015:45-46)

Menurut undang-Undang Sistem Peradilan Anak, pengertian diversi diatur dalam pasal 1 ayat 7, yakni "pengalihan penyelesaian perkara anak dari proses peradilan pidana ke proses di luar peradilan pidana". Dalam menyelesaikan perkara yang melibatkan anak, penegak hukum wajib mengupayakan diversi yang meliputi penyidikan, dan penuntutan sesuai dengan yang tercantum dalam sistem peradilan anak, kecuali apabila ditentukan lain dalam perundangundangan ini. Menurut pasal 2 ayat 2 UU SPPA: "Dalam sistem peradilan pidana anak, wajib diupayakan diversi, artinya diversi diupayakan dalam sistem peradilan pidana anak, yang meliputi: penyidikan dan penuntutan pidana anak yang dilaksanakan sesuai dengan ketentuan peraturan perundangundangan, kecuali ditentukan lain dalam undang-undang ini; Persidangan anak yang dilakukan oleh pengadilan di lingkungan peradilan umum; dan pembinaan, pembimbingan, pengawasan dan/atau pendampingan selama proses pelaksanaan pidana atau tindakan dan setelah menjalani pidana atau tindakan". (Kusno Adi, 2015:102)

Menurut Pasal 8 UU SPPA menyatakan: "Proses Diversi dilakukan melalui musyawarah dengan melibatkan Anak dan orang tua/walinya, korban dan orang tua/walinya, pembimbing kemasyarakatan, dan pekerja sosial profesional berdasarkan pendekatan Keadilan Restoraktif", sedangkan dalam pasal 9 UU SPPA menyatakan bahwa: "Kesepakatan Diversi harus mendapatkan persetujuan korban dan/atau keluarga anak korban serta kesediaan anak dan keluarganya, kecuali untuk: tindak pidana yang berupa pelanggaran; tindak pidana ringan; tindak pidana tanpa korban; atau nilai kerugian korban tidak lebih dari nilai upah minimum provinsi setempat". (Mualana Hasan, 2000:103)

Hal ini dipertegas dalam "United Nations Minimum Rules for the Administrator of Juveline (The Beijing Rules) diversi adalah pemberian kewenangan kepada aparat penegak hukum untuk mengambil tindakan-tindakan kebijaksanaan dalam menangani atau menyelesaiakan masalah pelanggar anak dengan tidak mengambil jalan formal anatara lain menghentikan 
atau meneruskan atau melepaskan dari proses peradilan pidana atau mengembalikan atau menyerahkan kepada masyarakat dan bentuk kegiatan pelayanan sosial lainnya. Penerapan diversi dapat dilakukan di dalam semua tingkatan pemeriksaan, dimaksudkan untuk mengurangi dampak negatif keterlibatan anak dalam proses peradilan tersebut".(Wiyono:34) Dalam pelaksanaan diversi, konsep yang dilakukan adalah mengalihkan penyelesaian masalah hukum terhadap anak dari proses formal keproses informal. Hal ini dilakukan untuk memberikan perlindungan kepada anak yang sedang menghadapi masalah dengan hukum. Masing-masing lembaga yang terlibat selanjutnya akan membahas konsep diversi ini untuk memberikan perlindungan terhadap anak tersebut. Selanjutnya para pihak ini akan berdiskusi dengan penegak hukum yang menangani kasus anak yang bermasalah tersebut. (Marlina, 2009:20)

Dalam melaksanakan konsep diversi, prinsipnya mengutamakan pendekatan dan memberikan kesempatan melalui tindakan persuasif kepada pelaku untuk berubah. Tindakan persuasif yang dilakukan petugas antara lain membina anak tersebut agar taat kepada hukum, dalam hal ini tindakan penangkapan, pemaksaan dan kekerasan harus dihindari oleh petugas. Karena dengan menggunakan kekerasan akan menimbulkan keterpaksaan bagi si anak dalam menegakan hukum. Cara ini dilakukan sebagai bentuk upaya baru dalam menegakan hukum di masyarakat, bukan untuk mengabaikan penegakan hukum dan keadilan di masyarakat. (Nasir Jamil, 2012:22)

Pada dasarnya lembaga peradilan yang menangani perkara pidana yang dilakukan oleh anak dibuat untuk menciptakan ketenangan bagi pelaku, oleh karenanya dalam mengambil keputusan terhadap anak harus berlandaskan pada kepastian hukum agar perlakuan dan jaminan dari aparat penegak hukum terhadap anak dibedakan dengan jaminnan terhadap orang dewasa. Sehingga dengan ditegakannya proses hukum ini, masa depan anak sebagai objek hukum tidak diabaikan (Marlina, 2009:90).

\section{Hubungan Konsep Restorative Justice dengan Konsep Diversi Dalam Penyelesaian Perkara Anak}

Proses restorative justice dalam menyelesaikan perkara diluar sistem peradilan pidana yakni dengan dilibatkannya pelaku, korban berikut orang tua/walinya, , masyarakat dan pihak-pihak lain yang dianggap berkepentigan untuk penyelesaian masalah kejahatan tersebut. Cara ini merupakan alternatif baru penyelesaian perkara pidana yang dilakukan oleh anak.

Restoratife justice mengandung pengertian pelanggaran atau perbuatan melawan hukum yang dilakukan oleh masyarakat atau orang yang mengakibatkan rusaknya norma hukum yang selama ini sudah berlaku dengan baik. (Wagiati, :42)

Menurut Jeff Christian mengatakan bahwa: "restorative justice adalah sebuah penanganan tindak pidana yang tidak 
hanya dilihat dari kacamata hukum pidana, tetapi juga dikaitkan dengan aspek moral, sosial ekonomi, agama dan adat istiadat lokal, serta berbagai pertimbangan lainnya." (Wiyono 2015:43) Rstorative justice menekankan pada keadilan untuk pemulihan anak sebagai pelaku tindak pidana, korban dan masyarakat yang merasa terganggu dengan adanya tindak pidana tersebut.

Dengan menggunakan restirative justice, diharapkan peradilan anak dapat: a. Mengurangi jumlah anak-anak yang ditahan ataupun dipenjara, b. Menghilangkan stigma negatif terhadap anak, dan membina anak agar menjadi anak yang berguna di masa depan, c. Anak tidak lagi mengulangi perbuatannya dikemudian hari, sehingga anak tersebut bertanggung jawab atas perbuatannya, $d$. Berkurangnya beban pekerjaan lembaga pengadilan, e. Mengurangi pengeluaran negara, f. Melibatkan orang tua dan masyarakat dan berperan dalam menanggulangi pelanggaran hukum yang dilakukan oleh anak, g. Mengembalikan anak kepada lingkungannya.

Menurut konsep ini, proses pemulihan anak melalui diversi, yakni menyelesaikan kasus yang menimpa anak melalui tindakan alternatif, yakni mengalihkan atau memindahkan dari proses diperadilan ke jalur informal diluar pengadilan melalui mediasi antara pihak pelaku dan korban dengan mediator oleh lembaga sosial yang ditunjuk. Hal ini dilakukan untuk menghilangkan penilaian negatif terhadap anak tersebut dengan dukungan berbagai komunitas sosial yang berkepentingan. (Wagiati Soetedjo dan Melani, Hal 134-136)

Restorative juctice memandang bahwa penyelesaian kejahatan tidak hanya menjadi kewajiban pemerintah, namun masyarakat juga bertanggung jawab berperan penting. Konsep ini membangun pemahaman bahwa dampak negatif yang diakibatkan karena kejahatan harus diperbaiki, baik itu untuk korban, maupun bagi pelaku. Penanganan penyelesaian masalah kejahatan melalui konsep ini memberikan pemahaman dan kesempatan kepada masyarakat untuk ikut berpartisipasi dalam menyelesaikan tindak pidana yang dilakukan oleh anak. Kerangka berfikir dalam konsep ini adalah berupaya untuk mencarikan alternatif penyelesian tindak kejahatan yang dilakukan oleh anak namun tidak menggunakan hukuman pidana dalam menyelesaikan kasusnya. Hal ini dilakukan untuk memberikan rasa keadilan dan prikemanusiaan dengan tidak mengesampingkan hak pelaku maupun korban melalui upaya yang dilakukan oleh mediator ketika melakukan mediasi terhadap korban dan pelaku sebagai bentuk pelaksanaan konsep restoratfe justice bagi para pihak yang terlibat. (Marlina, 2009:24-25).

Persyaratan yang harus terpenuhi untuk melaksanakan restorative justice ini antara lain: a. Adanya pengakuan bersalah dari pelaku, b. Pihak korban menyetujui untuk dilaksanakan penyelesaian kasus melalui jalur alternatif sesuai dengan aturan yang berlaku, c. Pihak kepolisian dan kejaksaan sebagai lembaga yang berwenang melakukan penyidikan 
menyetujui dilaksanakannya alternatif tersebut, d. Adanya dukungan dari masyarakat dalam penyelesaian kasus tersebut melalui jalur alternatif.

Kasus-kasus yang dapat diselesaikan dengan menggunakan konsep restorative justice ini antara lain: a. Perbuatan yang dilakukan bukan merupakan kenakalan yang melanggar kepentingan masyarakat umum, dan melanggar lalu lintas, b. Perbuatan yang dilakukan bukan tindak pidana berat seperti pembunuhan, atau yang menimbulkan luka berat dan cacat permanen, c. Perbuatan yang dilakukan bukan jenis pelanggaran terhadap kesusilaan yang menyangkut kehormatan orang lain.

Dengan kata lain, kasus-kasus yang dapat diselesaikan dengan menggnakan konsep restorative justice ini adalah kasus-kasus yang bersentuhan dengan perbuatan pidana, baik itu yang sudah masuk dalam sistem peradilan pidana maupun yang belum masuk sistem peradilan pidana.(Wiyono:221-222)

Pelaksanaan kebijakan dalam penegakan hukum di masyarakat merupakan bagian dari kebijakan sosial, termasuk juga kebijakan yang dibuat oleh lembaga legislatif dalam menanggulangi kejahatan. Menanggulangi kejahatan merupakan bagian dari menegakan hukum. Untuk menanggulangi kejahatan, semua komponen dalam sistem hukum harus dilibatkan. ( Ruben Achmad 2005:12)

Dalam hukum pidana, penanggulangan masalah kejahatan terbagi menjadi dua jalur, pertama dengan menggunakan jalur "penal" (hukum pidana) dan "non penal" (diluar hukum pidana). Dalam penyelesaian dengan jalur non penal, proses yang dilakukan mengacu kepada sistem hukum dalam acara pidana. Penyelesaian perkara ini melibatkan aparatur penegak hukum seperti kepolisian, kejaksaan, pengadilan, lembaga pemasyarakatan. Penyelesaian mealui jalur penal lebih difokuskan kepada sifat represive "pencegahan/pemberantasan/penumpasa n" setelah terjadi kejahatan. Lain halnya dengan penyelesaian masalah melalui jalur non penal, yang lebih memfokuskan pada sifat preventife "pencegahan/penangkalan/pengendalian" sebelum terjadinya kejahatan. Penyelesaian dengan menggunakan jalur ini lebih menekankan pada penanaman nilai-nilai yang bersifat keagamaan, pembinaan oleh tokoh-tokoh masyarakat, memberikan kegiatan-kegiatan positif bagi pelaku. Penyelesaian permasalahan kejahatan dapat dilakukan melalui jalur pengadilan maupun non pengadilan. (Bunadi Hidayat, 2010:34)

Dalam menanggulangi kejahatan dengan melalui jalur non penal, upaya yang dilakukan melibatkan aparat penegak hukum dan masyarakat namun tidak menggunakkan hukum sebagai alat unttuk menyelesaikan perkara, hal ini untuk menghindarkan stigma negatif dari masyarakat terhadap si pelaku. Konsep ini lebih menekankan penyelesaian perkara dengan menggunakan jalur informal sebagai bentuk alternatif dalam penyelesaian tindakan kejahatan yang telah terjadi dengan melibatkan pihakpihak yang dianggap berkepentingan 
untuk mengubah sikap dan perilaku pelaku kejahatan.

Tindakan penyelesaian perkara kejahatan anak ini diatur dalam United Nations Standard Minimum Rules for the Administration of Justice (The Beijing Rules) butir 11 yang menyatakan bahwa: "diversi merupakan proses melimpahkan anak yang berkonflik dengan hukum dari sistem peradilan pidana kepada sistem informal seperti mengembalikan kepada lembaga sosial masyarakat, baik pemerintah negara maupun nonpemerintah. Tindakan ini dilakukan untuk menghindari efek negatif terhadap jiwa dan perkembangan anak. Diversi dilaksanakan oleh petugas dengan melakukan kewenangan yang disebut diskresi." (Bunadi Hidayat, 2010;14-19)

Kewenangan diskresi terletak pada kebijakan penyidik di kepolisian dalam memproses perkara, apakah diteruskan atau dihentikan. Tindakan keputusan diskresi ini diambil secara spontan oleh penyidik dengan mempertimbangkan berbagai macam hal berkaitan dengan kepentingan terhadap si pelaku.(Kusno Adi, 2015:20)

Kebijakan dalam memberikan diskresi berupan tindakan diversi yang dilakukan oleh penyidik di kepolisian merupakan bentuk kebijakan agar si pelaku terhindar dari proses perkara melalui peradilan formal, diversi yang dilakukan yakni untuk melindungi pelaku dan membina pelaku agar tidak terjerumus dalam kejahatan yang lebih besar di kemudian hari. .(Kusno Adi, 2015:23)

Bentuk tangggung jawab pelaku dalam melaksanakan restorative justice adalah memberikan ganti rugi atau dalam bentuk lainnya kepada korban selain menjalani pidana. Pelaku akan dimintai juga perjanjian tertulis yang di tandatangani oleh pelaku dengan disaksikan dan diawasi pelaksanaannya oleh masyarakat untuk tidak lagi mengulangi perbuatannya di kemudian hari. Sedangkan bentuk tanggung jawab pelaku terhadap korban selain diberikan ganti rugi, di berikan juga penyembuhan, penderitaan, maupun keruguan atas sakit yang diderita pelaku. Hal penting yang harus diperhatikan dalam pelaksanaan diversi ini adalah pertanggungjawaban pelaku terhadap korban sampai selesai. (Wiyino:223)

Dari pemaparan diatas, dapat ditarik kesimpulan antara hubungan diversi dengan restoratife justice dalam pelaksanaan peradilan anak adalah bukan pembalasan terhadap perilaku anak, namun ditekankan kepada pemulihan ke keadaan sebelum tindakan kejahatan tersebut di lakukan, hal ini agar nama baik dan masa depan anak terlindungi dari stigma negatif di masyarakat, sedangkan penyelesaian kasus nya dialihkan dari peradilan formal ke peradilan informal.

\section{Pelaksanaan Diversi terhadap anak pelaku tindak pidana di kota Tangerang}

Secara ringkas diatas sudah diuraikan mengenai pemaparan konsep diversi, yakni mengalihkan penyelesaian kasus hukum terhadap anak dari sistem peradilan formal ke peradilan informal. Dalam menyelesaikan kasus yang menimpa anak wajib diusahakan dengan 
diversi, dalam pengertian upaya yang harus dilakukan dalam proses penyelidikan, dan tuntutan pidana terhadap pelaku anak harus sesuai dengan perundang-undangan yang berlaku, kecuali apabila undang-undang menentukan lain. Menurut pasal 5 ayat 2 SPPA menyatakan bahwa: "Persidangan anak yang dilakukan oleh pengadilan di lingkungan peradilan umum; dan pembinaan, pembimbingan, pengawasan dan/atau pendampingan selama proses pelaksanaan pidana atau tindakan dan setelah menjalani pidana atau tindakan".

Dalam SPPA diatur bahwa penerapan diversi ini hanya untuk kategori anak berusia dibawah 18 tahun atau belum pernah menikah serta tidak pernah melakukan tindak pidana sebelumnya. Dalam satu wilayah hukum, pemberian kesempatan diversi ini hanya sekali untuk seumur hidup. Pemberian diversi ini juga hanya untuk kejahatan - kejahatan ringan, bukan kejahatan berat seperti pembunuhan, pencurian, pemerkosaan, narkoba, maupun tindak pidana lainnya yang ancamannya lebih dari tujuh tahun. (Hasil wawancara dengan Bripka Istanto Sudibyo, S.H, M.H, Kanit Reskrim Polres Tangerang Selatan)

Prinsip dalam melaksanakan diversi adalah keadilan terhadap kepentingan korban, tangggung jawab anak sebagai pelaku, kesejakteraan, menghindari pembalasan hukuman terhadap pelaku demi terciptanya ketertiban dan tegaknya hukum di masyarakat. Dalam memberikan diversi, aparat penegak hukum yang meliputi kepolisian, jaksa dan hakim akan mempertimbangkan layak tidaknya pelaku diberikan kesempatan diversi, karena berbagai macam pertimbangan antara lain, jenis kejahatan yang dilakukan, usia anak, hasil olah kejadian, lembaga kemasyarakatan, kerugian yang diderita korban akibat perbuatan pelaku, perhatian masyarakat atas kasus tersebut, juga kesepakatan dan dukungan dari keluarga pelaku dan korban.

Bentuk kesepakatan dalam pelaksanaan diversi antara lain; perdamaian antara pelaku dan korban, baik itu disertai dengan ganti rugi maupun tidak, mengembalikan pelaku kepada pengawasan orang tua atau walinya, mengikut sertakan si pelaku dalam pelatihan lembaga pendidikan di masyarakat atau sejenisnya, pelayanan masyarakat. Setelah ada kesepakatan diantara pihak yang terlibat, hasil keputusan tersebut di tuangkan dalam bentuk keputusan. Dan keputusan ini wajib disepakati dan dilaksanakan terutama oleh si pelaku dengan diawasi oleh masyarakat dan pihak yang terlibat. Ketua pengadilan negeri setempat akan dimintai surat penetapan oleh pembimbing kemasyarakatan agar keputusan tersebut memiliki kekuatan, lalu penetapan tersebut diberikan kepada pihak-pihak yang terlibat agar turut serta mengawasi pelaksanaan keputusan tersebut.

Proses dalam menerapkan diversi harus diupayakan oleh penyidik kepolisian selambat-lambatnya tujuh hari dari dimulainya penyelidikan, sedangkan pelaksanaan diversi paling lambat dilaksanakan tiga puluh hari setelah diputuskan. Setelah upaya diversi berhasil 
disepakati, penyidikan dilanjutkan oleh penyidik dengan memberikan laporan penelitian kemasyarakatan dan berita acara diversi kepada penuntut umum.

Tindakan yang dilakukan oleh polres Tangerang Selatan setelah melakukan penyidikan adalah menangkap dan menahan pelaku yang diduga melakukan tindakan kejahatan. Kewenangan yang diberikan oleh undang-undang terhadap penyidik cukup luas, ketika melaksanakan tugasnya, penyidik berhak untuk mengurangi hak seorang terduga pelaku, namun tetap masih sebatas yang di amanatkan undang-undang SPPA pasal 30 .

Dalam melaksanakan tugasnya, penyidik berkoordinasi dengan jaksa penuntut umum melaksanakan penyelidikan sebagaimana telah di paparkan sebelumnya maksimal 1x24 jam ketika penyelidikan tersebut dimulai. Ketika penyelidikan, pelaku tidak ditahan asalkan mendapatkan jaminan dari orang tua atau walinya, atau jaminan dari lembaga bahwa pelaku tersebut tidak akan melarikan diri, menghlangkan barang bukti, maupun berjanji tidak mengulangi perbuatannya. Namun pelaku dapat ditahan apabila berusia lebih dari 14 tahun dan tindakan kejahatan yang dilakukan ancaman penjaranya lebih dari 7 (tujuh) tahun. (Ruslan Saleh, 1983:33)

Pengecualian penahanan terhadap anak dibawah usia 14 tahun ini di berikan sebagai bentuk kebijakan baru mengingat pada usia tersebut masih tergolong rentan, sehingga pembinaannya dikembalikan kepada masyarakat agar mendapatkan bimbingan rohani, jasmani dan kehidupan sosial si pelaku tetap dalam jaminan dari penjamin.

Apabila dalam rentang waktu 7 (tujuh) hari penahanan terhadap pelaku, penyidik belum mendapatkan cukup bukti, maka penahanan dapat diperpanjang selama-lamanya 8 (delapan) hari sesuai dengan permintaan penuntut umum, namun apabila penahanan yang kedua belum selesai juga, maka si pelaku wajib di keluarkan demi hukum untuk selanjutnya penahanannya dialihkan di LPAS. Apabila wilayah hukum tersebut tidak memiliki LPAS maka penahanan di lakukan di LPKS yang berada di wilayah hukum tersebut.

Untuk kepentingan penuntutan, penuntut dapat menahan pelaku maksimal 5 (lima) hari, namun apabila belum didapatkan cukup bukti maka penahanan oleh penuntut umum di perpanjang selama 5 (lima) hari, apabila melebihi waktu tersebut maka pelaku wajib di keluarkan demi hukum. Untuk kepentingan pemeriksaan di pengadilan negeri, hakim diperkenankan menahan pelaku selama 10 (sepuluh) hari, jika belum cukup bukti maka diperbolehkan diperpanjang paling lama 15 (lima belas) hari. Apabila melebihi waktu yang sudah ditetapkan belum didapatkan bukti, maka pelaku harus di keluarkan demi hukum. Untuk kepentingan pemeriksaan di tingkat kasasi, hakim diperkenankan untuk menahan pelaku selama-lamanya 15 (lima belas) hari. Hakim kasasi dapat meminta perpanjangan waktu penahanan kepada ketua mahkamah agung terhadap si pelaku maksimal 20 (dua puluh), apabila penambahan waktu ini berakhir 
namun hakim di tingkat kasasi belum memvonis pelaku, maka pelaku wajib di keluarkan demi hukum.

Ketika di mulainya penangkapan ataupun penahanan, pejabat yang berwenang wajib memberitahukan kepada pelaku maupun orang tua atau walinya tentang hak untuk didampingi oleh kuasa hukum untuk mendapatkan bantuan hukum, apabila pejabat tersebut tidak memberitahukan ketentuan tersebut, maka penahanan dan penangkapan terhadap pelaku dinyatakan batal demi hukum. (Dahlan Sinaga, 2017: 152-153)

Tindakan selanjutnya adalah penuntutan. Menurut KUHAP pasal 1 ayat 7 Penuntutan adalah: "penuntutan adalah tindakan penuntut umum untuk melimpahkan perkara pidana ke pengadilan negeri yang berwenang dalam hal dan menurut cara yang diatur dalam undang-undang dengan permintaan supaya diperiksa dan diputus oleh hakim dalam persidangan". Dalam hal pdana acara anak, penuntut umum akan melimpahkan kasus yang ditanganinya ke peradilan anak agar hakim dapat memeriksa dan memutus perkara anak tersebut di persidangan. Apabila belum terdapat penuntut umum dengan persyaratan seperti yang dimaksud sesuai dengan kasus yang dihadapi untuk menyelesaikan kasus anak, maka penuntut umum yangdi tugaskan adalah penuntut umum lain yang biasa menuntut perkara orang orang dewasa.

Dalam hal menjalankan tugasnya menangani kasus yang menimpa anak, penuntut umum wajib mengusahakan diversi paling lama 7 (tujuh) hari setelah berkas laporan perkara diterima, dan pelaksanaan diversi paling lambat dilaksanakan 30 (tiga puluh) hari. Penuntut umum wajib melaporkan berita acara apabila diversi berhasil diupayakan kepada ketua pengadilan negeri agar segera dibuatkan penetapan tertulis. Namun apabila diversi yang diupayakan oleh penuntut umum ini gagal, maka penuntut umum wajib membuat berita acara untuk disampaikan kepada ketua pengadilan negeri dan perkara segera dilimpahkan ke pengadilan disertai dengan laporan hasil penelitian masyarakat untuk segera dilaksanakan persidangan dan perkara segera di putuskan oleh hakim.

Setelah perkara anak dilimpahkan ke pengadilan, maka ketua pengadilan negeri wajib menentukan majelis hakim yang akan menangani perkara tersebut paling lama 3 (tiga) hari setelah berkas perkara dikirimkan oleh penuntut umum. Hakim yang ditugaskan menangani perkara tersebut wajib mengupayakan diversi paling lambat 7 (tujuh) hari, sehingga pelaksanaan diversi dapat dilaksanakan maksimal 30 (tiga puluh) hari. Sebetulnya, kelanjutan upaya diversi dapat dilakukan oleh hakim di ruang mediasi pengadilan negeri. Apabila upaya majelis hakim mengupayakan diversi berhasil, maka dibuatlah berita acara yang akan disampaikan kepada ketua pengadilan negeri untuk dibuatkan ketetapannya, namun apabila upaya diversi ini gagal maka hakim akan melanjutkan perkara ke tahap persidangan.

Ketika proses persidangan berlangsung, hendaknya anak beada pada 
ruang persidangan khusus anak, ijin hakim mengenai hal-hal yang begitupun ruang tunggunyapun harus meringankan bagi pelaku. Hakim juga dipisahkan dengan ruang tunggu orang dewasa. Jadwal sidang anak harus didahulukan dari orang dewasa, proses persidangan nya harus tertutup untuk umum, namun untuk pembacaan putusan boleh dilaksanakan dengan terbuka. Selama proses persidangan, hakim mewajibkan anaktersebut di dampingi oleh orang tua atau walinya, atau kuasa hukumnya dan pembimbing kemasyarakatan.

Persidangan bersifat tertutup agar tercipta rasa kekekluargaan, sehingga anak akan merasa tenang menceritakan semua peristiwa yang dilakukannya dengan jujur dan terbuka selama proses persidangan berlangsung. Setelah hakim membacakan surat dakwaan, hakim akan meminta pembimbing kemasyarakatan melaporkan hasil penelitiannya mengenai anak tersebut tanpa kehadiran anak di ruang persidangan, kecuali apabila hakim menentukan lain. isi laporan tersebut antara lain mengenai: a. Data probadi, keluarga, pendidikan dan kehidupan sosial anak, b. Latar belakang tindak pidana yang dilakukan anak, c. Keadaan korban, d. Hal-hal lain yang dianggap perlu disampaikan, e. Berita acara diversi, f. Kesimpulan dan rekomendasi dari pembimbing kemasyaraakatan.

Pelaksanaan sidang anak dilakukan setelah mendengarkan kesaksian dari korban, ketika pemeriksaan saksi, pelaku menunggu diluar ruang persidangan, maka sebelum hakim menjatuhkan putusan hendaknya pelaku di berikan nasihat oleh orang tua atau walinya atas memberikan gambaran tentang perkara yang di sangkakan kepada pelaku, sehingga ketika memberikan putusan, hakim akan mempertimbangkan laporan dari lembaga kemasyarakatan sebelum putusan dijatuhkan. Jika hakim tidak mempertimbangkan laporan penelitian dari masyarakat maka putusan yang dijatuhkan akan batal demi hukum.

Anak diperkenankan tidak menghadiri persidangan ketika putusan dibacakan, dan pembacaan putusan hakim terbuka untuk umum, namun berkenaan dengan identitas para pelaku dan korban akan di rahasiakan serta tidak diperbolehkan untuk dipublikasikan, kalaupun di liput oleh media massa cukup mencantumkan inisial saja. Pengadilan wajib memberikan salinan putusan kepada pelakuatau kuasa hukumnya paling lambat 5 (lima) hari setelah ptusan dibacakan.

Upaya diversi wajib dilakukan oleh pengadilan negeri dari mulai tingat peyidikan, dan pemeriksaan. Kata wajib disini mengandung pengertian bahwa upaya diversi ini harus dilakukan oleh pejabat-pejabat yang terkait dengan penyelesaian perkara yang menimpa anak, mulai dari penyidik, jaksa penuntut umum dan oleh hakim. Menurut pasal 95 Undang-Undang SPPA mengatakan bahwa: "bagi penegak hukum anak apabila tidak melakukan upaya diversi haruslah diberi sanksi". (Pasal 96 UU SPPA) Walaupun dalam pelaksanaannya seringkali terjadi perdebatan, karena dikhawatirkan terjadi diskriminasi antara penegak hukum apabila lalai 
Jurnal Pendidikan Kewarganegaraan

Vol. 6 No. 2 September 2019
Journal of Civics and Education Studies p-ISSN 2302-0865 | e-ISSN 2621-346X melaksanakan diversi, sehingga ada kemungkinan aparat penegak hukum akan melakukan judicial review terhadap pasal ini.

\section{Kesimpulan}

Pelaksanaan diversi terhadap anak yang berhadapan dengan masalah hukum wajib diupayakan oleh aparat penegak hukum sebagai bentuk perlindungan terhadap masa depan anak dari pengaruh dan stigma negatif di masyarakat. Penanganan masalah anak yang berhadapan dengan hukum diupayakan diselesaikan dengan menggunakan jalur di luar peradilan. Adapun untuk memaksimalkan kinerja dari aparat pegek hukum ini harus mendapatkan dukungan dari berbagai pihak yang terlibat dengan peristiwa kejahatan yang dilakukan oleh anak meliputi orang tua atau wali dari pelaku dan korban, aparat penegak hukum dan lembaga masyarakat. Namun tidak semua kejahatan yang di sangkakan terhadap anak dapat diupayakan diversi, diantaranya apabila kejahatan yang dilakukan diancam dengan hukuman lebih dari 7 (tujuh) tahun atau dengan kategori kejahatan berat. (Nasir Jamil, 2012:23)

Unsur-unsur yang terlibat dalam penyelesaian perkara anak hendaknya memberikan memahami mengenai penyelesaian perkara anak dapat dilakukan dengan jalur alternatif lain di luar lembaga peradilan. Integritas dari aparat penegak hukum dalam menangani perkara anak wajib memahami dan mematuhi aturan-aturan yang tercantum dalam sistem peradilan pidana anak.

\section{Referensi}

Achmad, R. (2005). Upaya Penyelesaian Masalah Anak yang Berkonflik dengan Hukum di Kota Palembang, Jurnal Simbur Cahaya, Nomor 27, 2005.

Adi, K. (2015). Diversi Tindak Pidana Narkotika Anak. Malang: Setara Pres/

Ali, Z. (2009). Metode Penelitian Hukum, Sinar Grafika, Palu, Agustus 2009, Hal 105.

Diana, L. (2011). "Penyakit Sosial dan Efektifitas Hukum di Indonesia", Jurnal Ilmu Hukum, Fakultas Hukum Universitas Riau, Volume 2, No. 1 Februari 2011.

Djamil, M. N. (2012). Anak Bukan Untuk di Hukum (Catatan Pembahasan UU Sistem Peradilan Pidana Anak (UUSPPA)). Jakarta: Sinar Grafika.

Gultom. (2014). Perlindungan Hukum Terhadap Anak dalam Sistem Peradilan Pidana Anak di Indonesia. Bandung: Refika Aditama.

Hanitijo, R. (1982). Metodologi Penelitian Hukum. Semarang: Ghalia Indonesia.

Hidayat, B. (2010). Pemidanaan Anak di Bawah Umur: Bandung. Alumni

Marlina. (2009). Peradilan Pidana Anak di Indonesia Pengembangan Konsep Diversi dan Restorative Justice. Medan: Reflika Aditama.

Rasjidi, L. (2010). Perlindungan terhadap saksi dan korban tindak pidana, Remaja Rosdakarya Bandung Indonesia.

Saleh, R. (1983). Perbuatan Pidana dan Pertanggungjawaban Pidana dua pengertian dasar dalam hukum pdana. Jakarta: Aksara Baru. 
Jurnal Pendidikan Kewarganegaraan

Vol. 6 No. 2 September 2019

Sinaga, D. (2017). Penegakan Hukum dengan Pendekatan Diversi. Yogyakarta: Nusa Media.

Sudarto. (1986). Kapita Selekta Hukum Pidana. Bandung: Alumni.

Wadong, M. H. (2000). Advokasi dan Hukum Perlindungan Anak. Jakarta: Grasindo.

Wahjono, A. \& Rahayu, S. (2010). Tinjauan Tentang Peradilan Anak di Indonesia Asfinawati, dkk. Edisi Buku Saku 3 Bagaimana Bila: Anak Anda Menjadi Korban atau Pelaku Tindak Pidana.

Wiyono, R. (2015). Sistem Peradilan Pidana Anak di Indonesia. Ngunut: Sinar Grafika. 
Jurnal Pendidikan Kewarganegaraan

Vol. 6 No. 2 September 2019
Journal of Civics and Education Studies p-ISSN 2302-0865 | e-ISSN 2621-346X

[ halaman ini sengaja dikosongkan ] 